\title{
The Celtic Element in Gallo-romance Dialect Areas
}

\author{
† Fean $\{e \mathcal{D} \hat{u}$
}

\section{Introduction}

The Gallo-Romance languages are derived from forms of vulgar Latin spoken by the descendants of Romanised Gaulish-speaking peoples, and influenced by the Germanic speech of the Frankish invaders who gave France its name. If few scholars have doubted the Latin roots of the language, the influence of both the Celtic substrate and of the Germanic superstrate have long been a controversial matter not only for scientific but also for ideological reasons.

Relying on modern geolinguistics, I shall study some of Jules Gilliéron's ALF (Atlas Linguistique de la France) maps as well as Breton ones from Pierre Le Roux's Atlas Linguistique de la Basse-Bretagne and Jean Le Dû's Nouvel Atlas Linguistique de la Basse-Bretagne. I shall try to show that several of these maps reveal the presence of ALF data whose origin is clearly Celtic and not Germanic, as has been presented by specialists of the French language, such as von Wartburg (1922-2002).

Study of the Atlas Linguarum Europae (ALE) and the Atlas Linguistique Roman (AliR) has shown that borders between languages and even language families are not impermeable to exchanges. It is high time to overcome language barriers and to bring about a new vision of the history of languages.

\section{The changing status of Gaulish}

\subsection{Celtomania}

Consciously or not, the development of linguistic ideas has always been underpinned by political or philosophical preconceptions. In France, many authors as early as the Renaissance began, for patriotic purposes, to magnify the Gaulish element in French as a means to pay tribute to their pre-Roman heritage. Due to a pun associating the word Gallia 'Gauls' and gallus 'rooster', this bird became the symbol of the kings of France. Celtomania became popular with the publication in Paris, in 1703, of Antiquité de la nation et de la langue des Celtes, autrement appelléz Gaulois 'Antiquity of the nation and the language of the Celts, otherwise known as Gauls', the work of the Breton Paul-Yves Pezron. Breton, to Pezron, was the direct descendant of the language of Gomer, Japhet's eldest son, Noah's grandson. ${ }^{1}$

1. Following Pezron, Theophilus Evans wrote Drych y prifoesoedd in 1713, in which he says the same thing about Welsh. It is for this reason that so many Welsh today claim it is the 'oldest language in Europe'. 
Following Pezron, several Breton dictionaries were published, in particular the Dictionnaire de la langue Bretonne (Dictionary of the Breton Language) by Dom Le Pelletier, printed in Paris in 1752, which was very influential in France.

Several 1789 revolutionaries considered the mass of the French people to be descendants of the Gauls, while the nobility's forefathers had been Germanic conquerors. Thus, Sieyès, in a 1789 pamphlet Qu'est-ce que le Tiers Etat? 'What is the Third Estate?', wrote:

The Third Party [the common people] must not fear to go back in time. ... why would they not send back to the forests of Franconia all those families who still have the foolish claim to be from the race of conquerors, and to have inherited the rights of conquest? $^{2}$

One can assess the scope of the doctrine when we read the following statement in Diderot's Encyclopedia:

...our French is none other than the Gaulish of the old Druids, imperceptibly disguised by all the changes necessarily brought about by the succession of centuries and the ever-changing circumstances (1751-72: 259). ${ }^{3}$

Celtomania reached its peak with the foundation, in 1803, during Napoleon's Empire, of the Académie Celtique 'The Celtic Academy'. In its inaugural session of March 1805, the Academy assigned itself the following mission:

The dual purpose of the Academy is as important, as useful as it is determined; it is the research of Celtic language and antiquities... Thus our goal must be, $1^{\circ}$. To find the Celtic language in the ancient authors and monuments; in the two dialects of this language that still exist, Breton and Welsh, and even in all the popular dialects, the patois and jargon of the French empire, as well as the origins of the languages and place names, monuments and uses that were derived from them, to provide dictionaries and grammars of all these dialects, that we must hasten to inventory before their total destruction; $2^{\circ}$. To collect, write, compare and explain all the antiquities,

2. Le Tiers ne doit pas craindre de remonter dans les temps passés. ... pourquoi ne renverrait-il pas dans les forêts de la Franconie toutes ces familles qui conservent la folle prétention d'être issues de la race des conquérants, et d'avoir succédé à des droits de conquête?

3. ... notre françois n'est rien autre chose que le gaulois des vieux Druides, insensiblement déguisé par toutes les métamorphoses qu'amenent nécessairement la succession des siecles \& les concours des circonstances qui varient sans cesse. 
all the monuments, all the customs, all the traditions; in a word, to make the ancient statistics of the Gauls, and to explain ancient times by modern times. ${ }^{4}$

This institution, which had a positive part in inspiring the first collection of popular traditions in the First French Empire and giving birth to future folklore and ethnological studies, collapsed after the fall of Napoleon in 1814. It has since been criticised for overemphasising France's Celtic heritage and even ridiculed by scholars for having exaggerated the Gaulish influence on French.

\subsection{Bretonism}

The ostracism that befell Celtic was further intensified in the $19^{\text {th }}$ century with the development of the "Bretonist" theory popularised by the historian La Borderie, and among linguists by Joseph Loth's thesis (1883) on the Breton immigration into Armorica from the 5 th to the $7^{\text {th }}$ centuries of our era. It put forward the idea that the Breton language had been imported wholly from Britain into the Armorican peninsula by emigrants fleeing the Anglo-Saxon invasions. According to Loth, all traces of Gaulish had by then disappeared and the country had been totally Romanised. From then on, any direct link between Breton and Gaulish was severed, and any allusion to a possible survival of Gaulish was rejected as a reversion to Celtomania. Brittany was no longer to be considered as a remnant of ancient Gaul, but as an extension of the British Isles on the mainland. Its language was deemed a sort of colonial language, paradoxically ranked among the Celtic insular languages. It is only in recent times that some scholars have taken a far less radical view on the possible survival of Gaulish (Falc'hun 1963, 1970, 1981; Fleuriot 1980; Evans 1990)

\subsection{The rise of Germanic}

The downfall of the ideas concerning a Celtic substratum in French left the door open to the glorification of the Germanic superstratum, which then rose to a prominent position for various reasons. First of all, Romance studies had been born in $19^{\text {th }}$-century German-speaking countries, thanks to the work of scholars from the University of Bonn, first and foremost Friedrich Diez (1794-1876). Second, the complete restructuring of the French university system, as a result of France's defeat in

4. Le double but que se propose l'Académie est aussi important, aussi utile que bien déterminé ; c'est la recherche de la langue et des antiquités celtiques... Ainsi notre but doit être, $1^{\circ}$. De retrouver la langue celtique dans les auteurs et les monumens anciens; dans les deux dialectes de cette langue qui existe encore, le breton et le gallois, et même dans tous les dialectes populaires, les patois et jargons de l'empire français, ainsi que les origines des langues et des noms de lieux, de monumens et d'usages qui en dérivent, de donner des dictionnaires et des grammaires de tous ces dialectes, qu'il faut se hâter d'inventorier avant leur destruction totale; $2^{\circ}$. De recueillir, d'écrire, comparer et expliquer toutes les antiquités, tous les monuments, tous les usages, toutes les traditions; en un mot, de faire la statistique antique des Gaules, et d'expliquer les temps anciens par les temps modernes. 
the 1870 Franco-Prussian War, was based on the model of the German system. When the first issue of Romanische Studien appeared in 1871, in Strasbourg (recently annexed into the German Empire), it was immediately followed by the French journal Romania, edited by two former students of German universities, Paul Meyer and Gaston Paris, the latter the translator of Friedrich Diez's Grammar of Romance Languages. In the following years, from 1879 to 1883, five German journals began in the Latin, Romance and French fields, which gave rise to the publication of Clédat's Revue des patois and Rousselot and Gilliéron's Revue des patois Gallo-Romans in 1887. The German influence is such that the Swiss Walter von Wartburg's Französisches Etymologisches Wörterbuch (FEW), written in German, is still the most important source for the study of French etymology. If we take into account D’Arbois de Jubainville's theory on the constitution of French place names, which popularised the idea that many French toponyms are based on the names of their Germanic owners, we see that the odds are in favour of the superstrate side. In short, Germanic benefited from an increased concern and support, while Celtic became a poor and somewhat embarrassing relative.

For reasons explained in section 1.1, the idea of possible Gaulish influence on French language and the survival of the Gaulish language in Brittany beyond the $5^{\text {th }}$ century has had trouble gaining acceptance among scholars and researchers proposing hypotheses regarding a possible Gaulish substratum in French face an uphill battle. The romantic image of Brittany in Europe and elsewhere has left such a lasting mark that any questioning of the extant theory is frowned upon as a sort of heresy.

\subsection{The role of geolinguistics}

Modern developments in geolinguistics have provided tools that allow us to travel back in time using previously unpublished or neglected dialect data. The linguistic atlases, far from remaining mere repositories of memories of bygone times, are now precious research tools for the history of languages. The time seems ripe to re-examine serenely the comparative contributions of Celtic - in this case, Gaulish - and Germanic in the formation of the French language. Why is French so different from its neighbouring Romance languages?

\subsection{Lower Brittany and Romance-speaking France}

The geographical area covered by the Atlas Linguistique de la France, as defined within the framework of Gilliéron's Conférence de dialectologie de la Gaule Romane, delivered from 1883-1926 in the Paris École Pratique des Hautes Etudes, ignored the allophone regions. It is interesting to reconnect Lower Brittany with this area and try to show that the Romance domain has very strong links with the Celtic one: is it not the case that the Breton word for the French language is ar galleg, from gallica lingua, i.e. Gaulish? Gallo-Romance has two faces. Joseph Loth himself showed that 500 of the most common Breton words - as well as the Welsh ones - are of Latin origin! 


\section{Examining some maps}

We will now discuss some maps, the configuration of which show the existence of an ancient linguistic continuum transcending the variety of languages within the territory that constitutes present-day France. The progressive extension of central French has pushed back many phonetic and lexical features to the fringes in areas that are now Lower Brittany, the Occitan and Franco-Provençal regions and, to a lesser extent, the northern and eastern borders of France. Former continuous areas have been broken up along the Atlantic at the estuary of the Loire river, which is both a barrier and a vector of new developments. The gap often widens along the coasts to join the Garonne, sometimes even moving southwards.

Our sources are the linguistic atlases and also, occasionally, forms that do not appear in the atlases but are uniformly used in Breton, such as brenn 'bran'. Isolated maps, as interesting as they may be, can only have an anecdotal meaning. We will therefore endeavour to highlight the presence of many such distributional areas. It is only the superimposition of similar maps that can lead us to plausible conclusions.

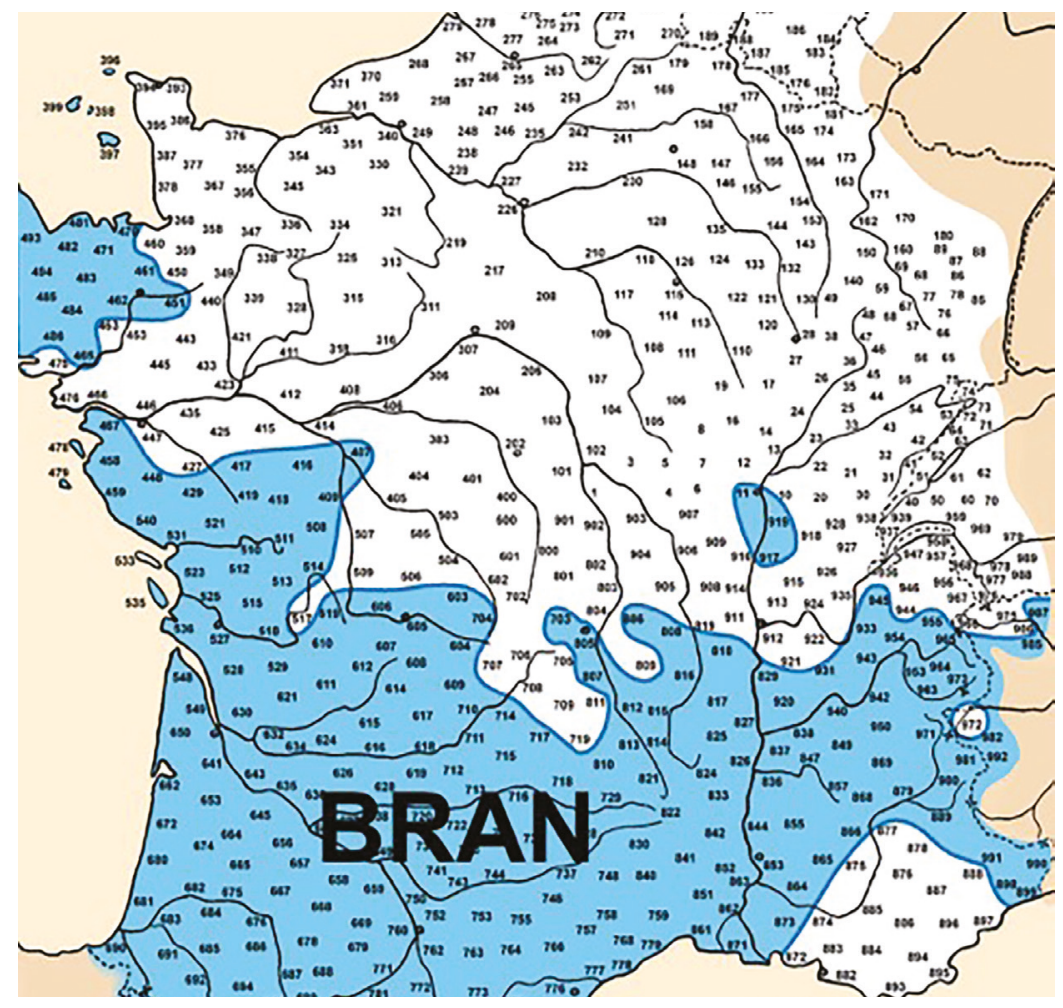

Fig. 1. The distribution of 'bran' (Breton brenn and Southern French bran) 


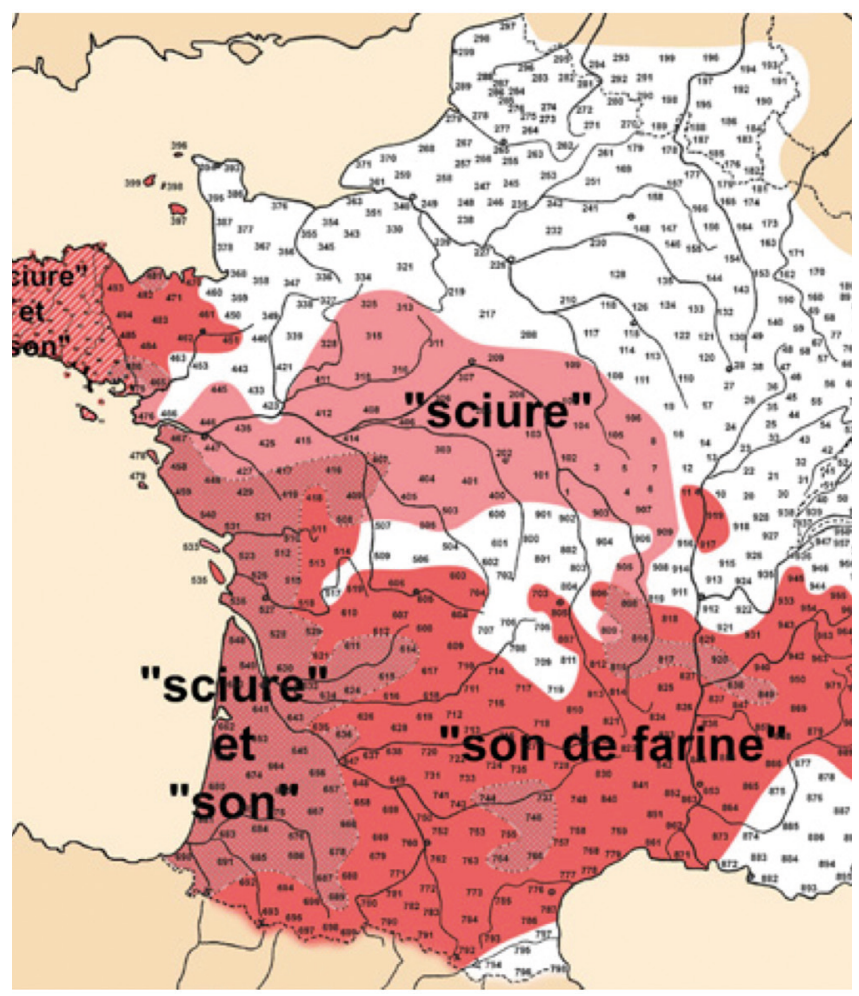

Fig. 2. The distribution of 'bran' with the meanings of 'bran' (French son (de farine) and 'sawdust' (French sciure)

\section{$2.1 \operatorname{Bren}(n)$ - Bran 'flour' and 'sawdust' (ALF 1207, 1242; Dict. bret.)}

According to the online CNRTL dictionary, the French word bran derives from a vulgar Latin *brennus of obscure origin, "perhaps Gaulish". It also reads: "but the corresponding words in Celtic languages are probably not indigenous". The word bren has everywhere in Breton the meaning of 'bran', and also, as in French, that of 'sawdust' in brenn-eskenn-literally, 'saw bran'.

Its presence in English, Welsh and Irish is generally attributed to a late borrowing from French. Fig. 1 demonstrating the variants of the word bran/bren, meaning 'bran of wheat' and 'sawdust' covers an area including western Brittany as well as the south and west of France. This continuum is broken at the mouth of the Loire by the intrusion of the word son, the French literary term meaning 'bran'. Let us now compare the maps in Figures 1 and 3. 


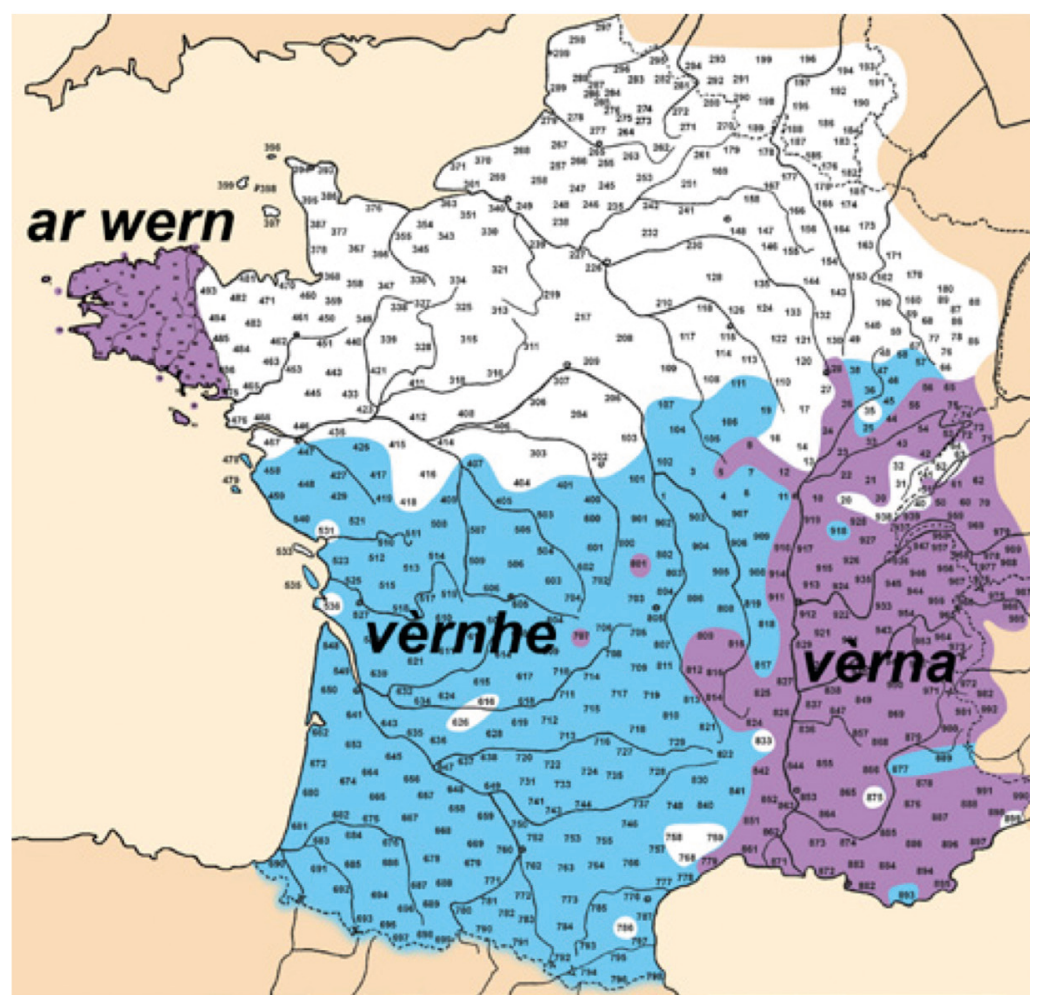

Fig. 3. The distribution of 'alder' (Breton gwern and Southern French vernhe/verna)

\subsection{Gwern - Vernhe/Vèrna 'alder tree' (ALF 74; Dict. bret.)}

Here, too, the Breton word gwern corresponds to a southern French word vernhel verna. The word is undoubtedly the Gaulish word uerna, which first means 'swamp' and also 'alder', a tree that grows in wetlands, and in Breton, incidentally 'mast of a ship'. We can find the former meaning of 'swamp' in Rouergue (Mistral, TDF, sv verno), but also in Limousin (ALAL, t. 1, c. 234). The other Celtic languages also share this word: Welsh gwern, Gaelic fern. The likeness to the bran maps (Figs. 1 and 2) supports the hypothesis of a Gaulish origin for gwern (Fig. 3). 


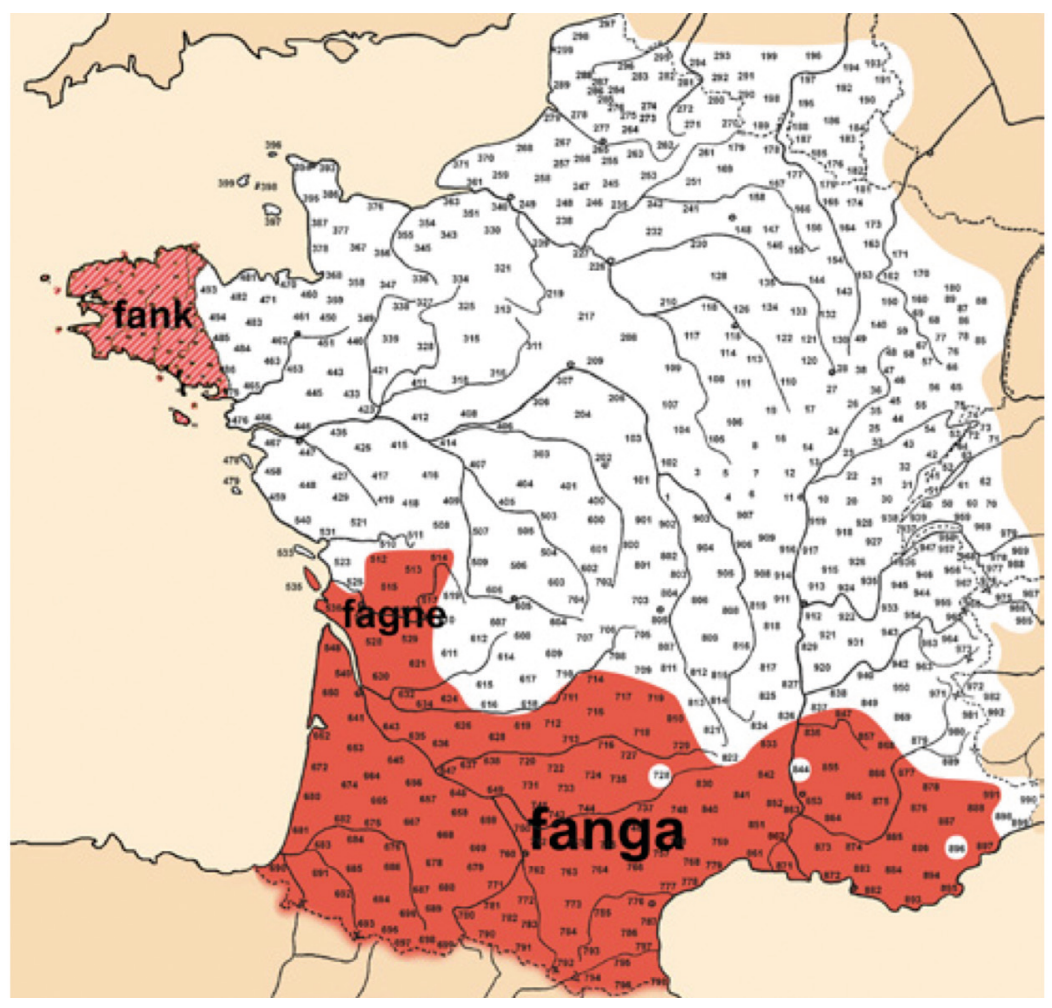

Fig. 4. The distribution of 'mud' (Breton fank and Occitan fanga)

\subsection{Fank -Fanga 'mud' (ALF 154; Dict. bret.)}

The lexical map can reveal the very old implantation of a word. On the 'mud' map (Fig. 4) of the ALF we find fanga in the south, while the Breton word is fank. This word is said to proceed from a Germanic *fanga, derived, with a -ga suffix, either from an old Frankish *fani, or from Gothic (= English fen, incidentally). It is odd, to say the least, that the Germanic form should once again be found in the most remote areas of the region, where the Frankish population was least firmly established.

\subsection{Merc'her/Merher mercredi 'Wednesday' (ALBB 142; ALF 839) ${ }^{5}$}

This map (Fig. 5) is similar to the previous one, but this time the gap extends from Loire to Gironde. The north of France is only represented by one point.

5. The dominant spelling used today is peurunvan. The author preferred 'orthographe universitaire'. We have included both: orthographe universitaire, merher, and peurunvan merc'her. 


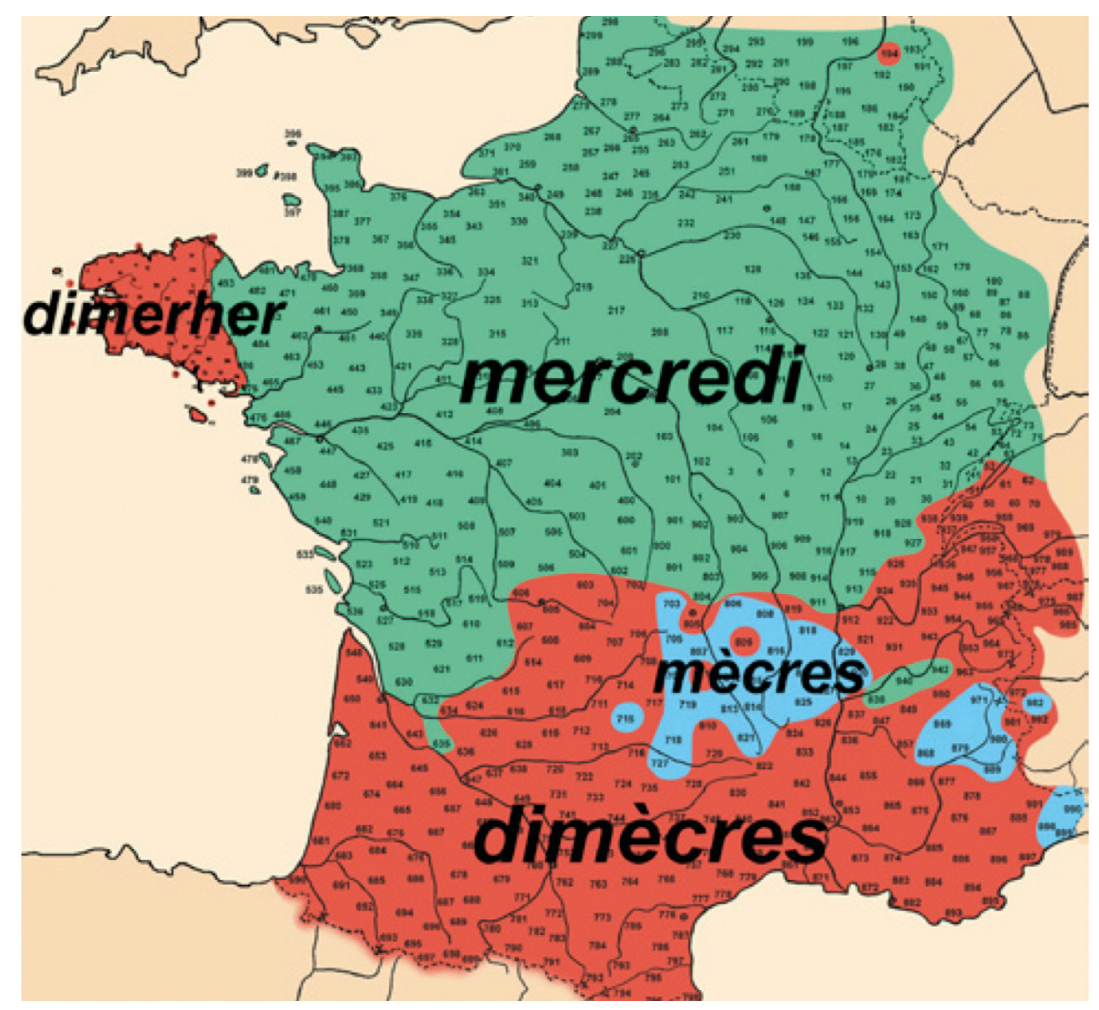

Fig. 5. The distribution of 'Wednesday' (Breton (di-)merher, French mercredi and Occitan dimècres)

There is no question of origin this time: the word is indisputably Latin.

The broken areas teach us, if it were necessary, that the construction from dies mercurii is older on the territory than the reverse adopted by central French Mercurii dies, which resulted in mercredi. Breton has kept alive the alternation between the simple merher form and the form composed with $d i-$, the first designating the day in general, the second, dimerher, the day closest to the moment when one speaks (i.e. next Wednesday or last Wednesday). This system can also be found in parts of the Massif Central (cf. Bras \& Brun-Trigaud 2014). This same structure applies to all the days of the week, including, in Breton, the pagan Sunday disul from dies solis instead of dies Dominica. 


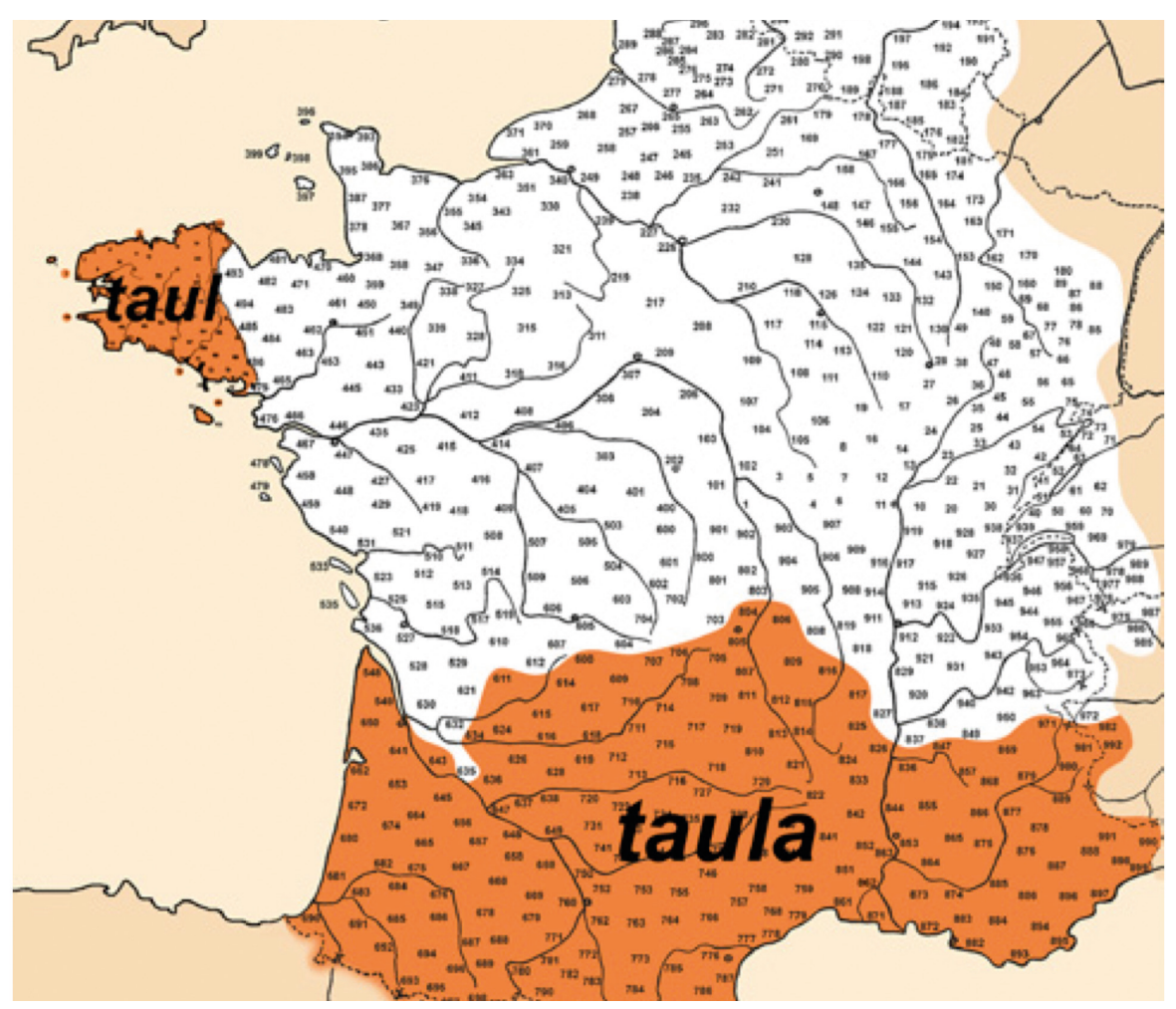

Fig. 6. The distribution of 'table' (Breton taul and Occitan taula)

\subsection{Taol taula 'table' (ALBB 578; ALF 1273)}

This map (Fig. 6) looks like the previous ones, but covers a smaller area in the east. It is the result of a phonetic phenomenon: Breton and Occitan have kept the diphthongised form of the direct derivative of tabula $>$ tabla $>$ taula; Old French, which also had this diphthong, restored the etymological $-b$ - under the influence of Latin and rejected the popular form which survived only in Brittany and the south of France. 


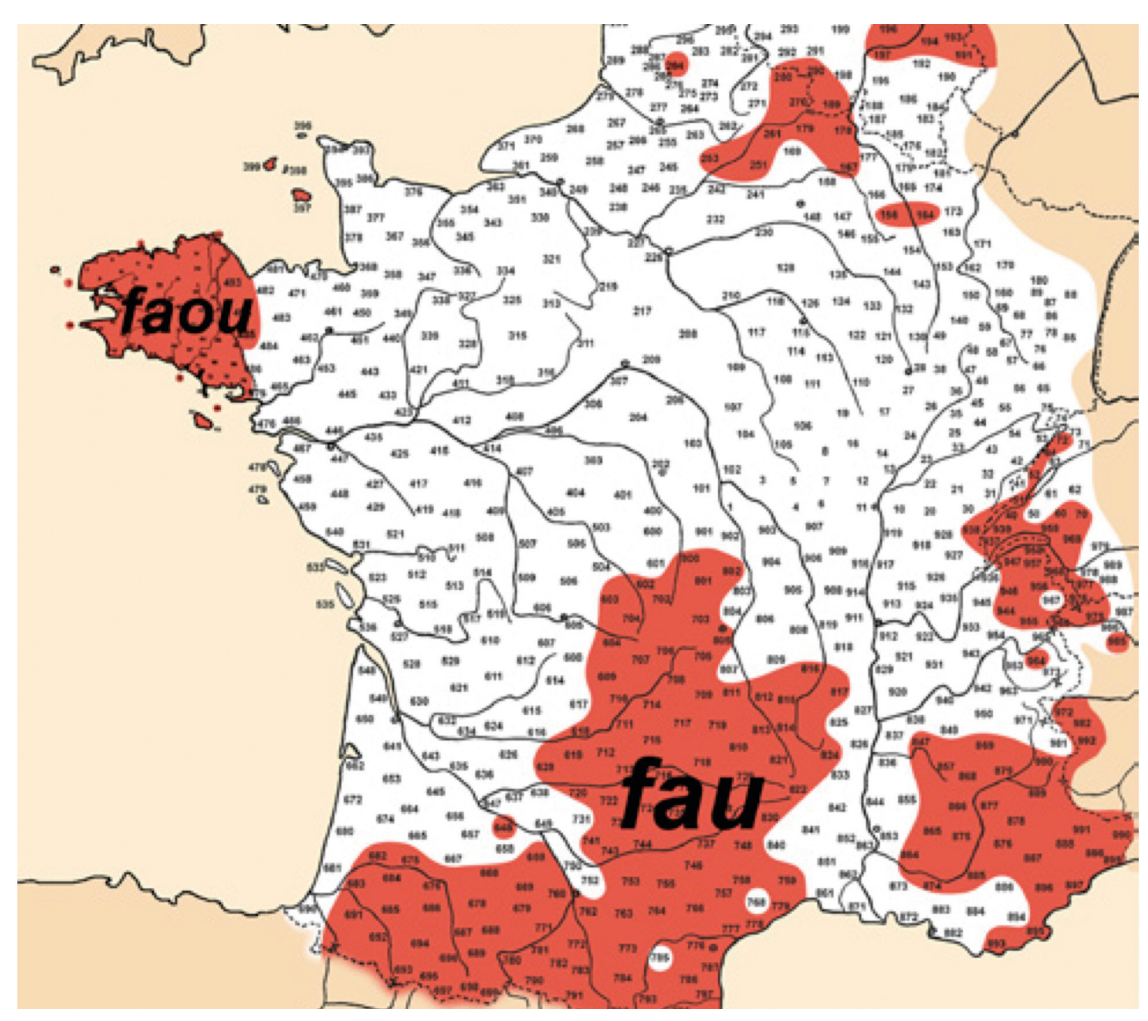

Fig. 7. The distribution of 'beech' (Breton faou and French fau)

\subsection{Faou - fau 'beech tree' (ALBB 196; ALF 690)}

Breton, like part of southern France, has retained fao, the reflex of Latin fagus. The conservative zone is even smaller than in previous maps. Areas of northern France, through which Germanic has spread, have also retained an old form, the word hêtre, from the Frankish *haister. It meant the young trunks that were used commercially to make sweeps or whips. The reign of Germanic-speaking kings had no doubt given more prestige to this Frankish word, which travelled just like the object it designated. It may also be that fagus became fou in French, an embarrassing homophone of the adjective meaning 'mad'.

This map (Fig. 7) looks like the previous ones, but covers a smaller area in the east. It is the result of a phonetic phenomenon: Breton and Occitan have kept the diphthongised form of the direct derivative of tabula $>$ tabla $>$ taula; Old French, which also had this diphthong, restored the etymological $-b$ - under the influence of Latin and rejected the popular form which survived only in Brittany and the south of France. 


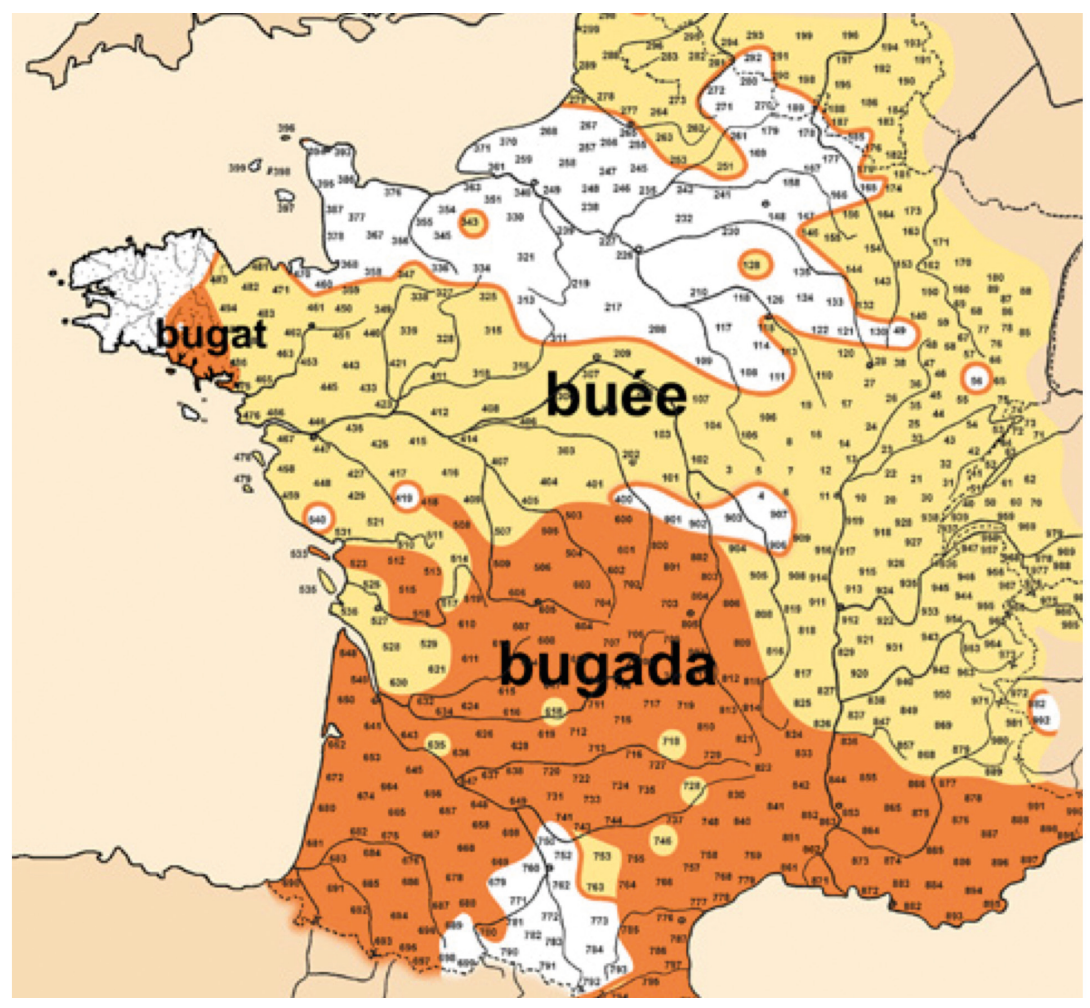

Fig. 8. The distribution of 'washing' (Lower Breton bugad, Northern French buée, and Southern French bugada)

\subsection{Bugat - bugada 'washing' (ALBB 48 and ALF 759)}

The south-east of Lower Brittany uses the word bugat which forms a phonetic continuum with the Occitan bugada from bucata 'lye'. Note the lenition of intervocalic $/ \mathrm{k} />/ \mathrm{g} /$ in both Breton and Occitan. It is derived from the verb *bucare, 'doing laundry' in Gallo-Romance. In Oill, northern French, the same word became buée with the loss of the intervocalic consonant. Here, again, the Germanic word for the 'beech' tree has been proposed as the source for this word and purportedly stemming from Frankish *bukkon, because the washing was originally done with ashes from this tree. This explanation is unlikely, however, considering that the map in Fig. 8) shows a very ancient bucata (bugada in modern Occitan), which is very distant from the early Germanic populated territories. 


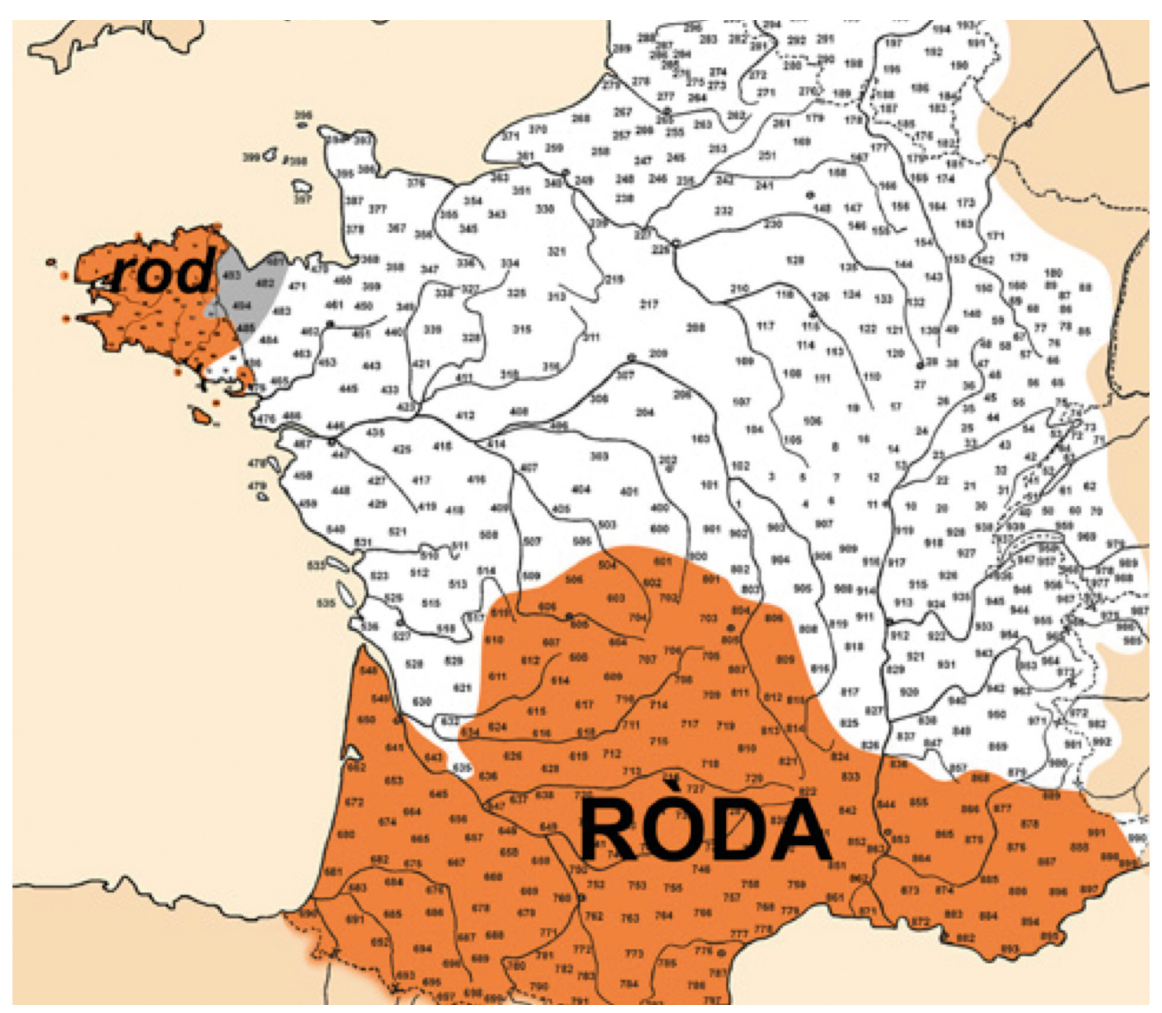

Fig. 9. The distribution of 'wheel' (Breton rod and Occitan ròda)

\subsection{Rod $\sim$ roda 'wheel' (ALBB 550 and ALF 1570)}

The Gaulish word roto- 'wheel' normally underwent the Celtic lenition process. The unvoiced intervocalic occlusive $-t->-d-$, which was retained in Breton and Occitan, also lenited French to $-d$-, then a step further to $-z$ - and was finally dropped so that it ended up in ruee, reue. Modern French roue is a back formation from the verb rouer. This map (Fig. 9) is similar to the previous ones. The Gaulish origin of roto is generally accepted. 


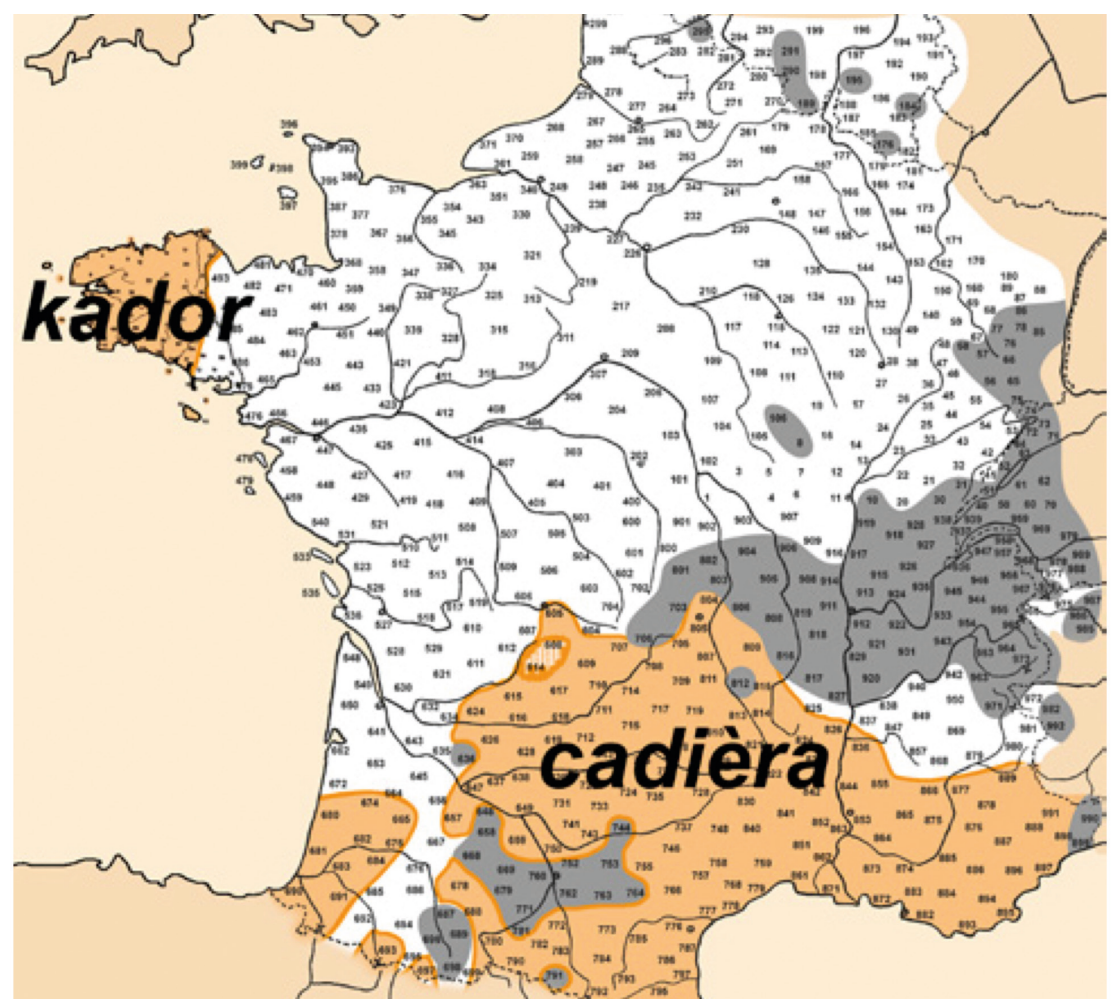

Fig. 10. The distribution of 'chair' (Breton kador and Occitan cadièra)

\subsection{Kador cadiera 'chair' ( (ALBB 406 and ALF 222)}

The Latinised Greek cathedra has kept its intervocalic $-d$ - in Breton and in Welsh (cadair) as well as in Occitan, ${ }^{6}$ an internal consonant that was dropped in northern French, as in the previous examples (see Fig. 10).

6. Welsh has retained the same word, cadair. 


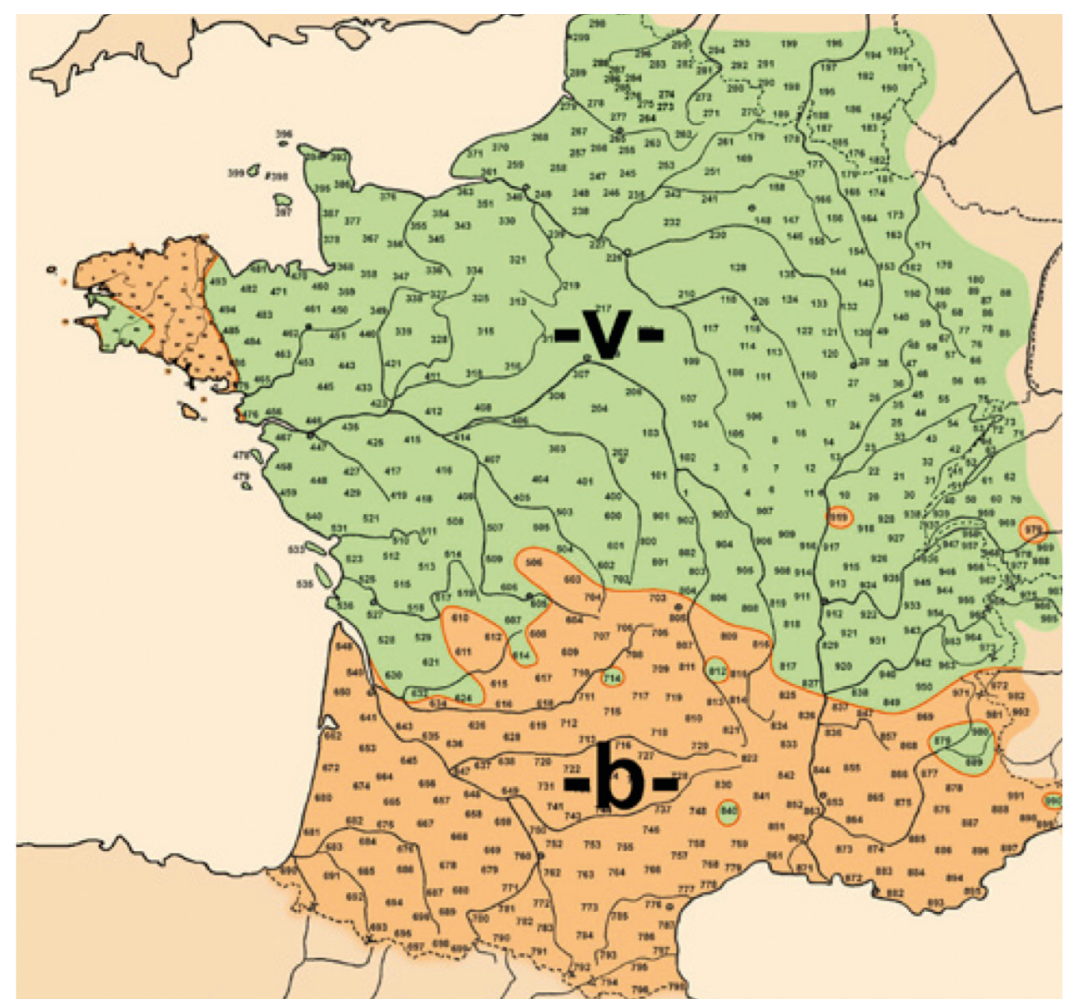

Fig. 11. The distribution of the medial - $b$ - in 'April' (Breton and Occitan) vs. $-v$ - (French)

\subsection{Ebrel avril 'April' (ALBB 464 and ALF 104)}

Another example of lenition completed in northern French: the internal $-p$ - in aprilis, lenited to $-b$ - in Breton and Occitan, was further lenited and became $-v$ The Avril form of the Quimper region of Breton, south-western Lower Brittany, was borrowed from French (see Fig. 11). 


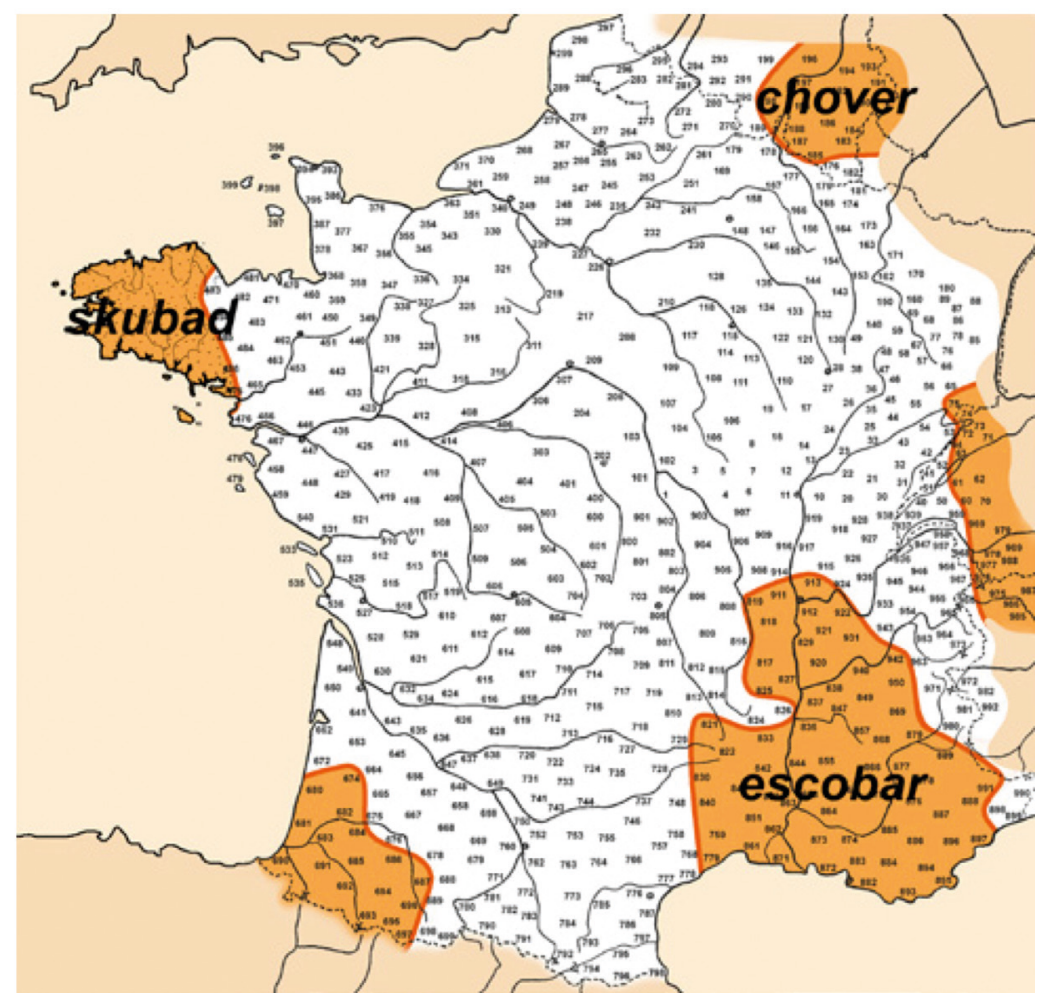

Fig. 12. The distribution of the verb 'to sweep' (Breton skubad, French escobar, chover)

\subsection{Balan -balai 'broom' and skubad - escobar 'to sweep' (NALBB 566 and ALF 109)}

The Gaulish word balano-, meaning the plant 'broom' (cf. $b$ - in Fig. 11) is at the origin of French balai balayer, meaning 'a broom' and 'to sweep' respectively (Le Dû \& Brun-Trigaud 2018). It is unquestionably of Celtic origin. The word 'to sweep' in modern Breton, however, is skubad, from scopa which is of Latin origin. As can be seen in Fig. 12, the word has survived on the fringes of French territory. In Lower Brittany, the plant name continues to be used under the forms of balan or banal 


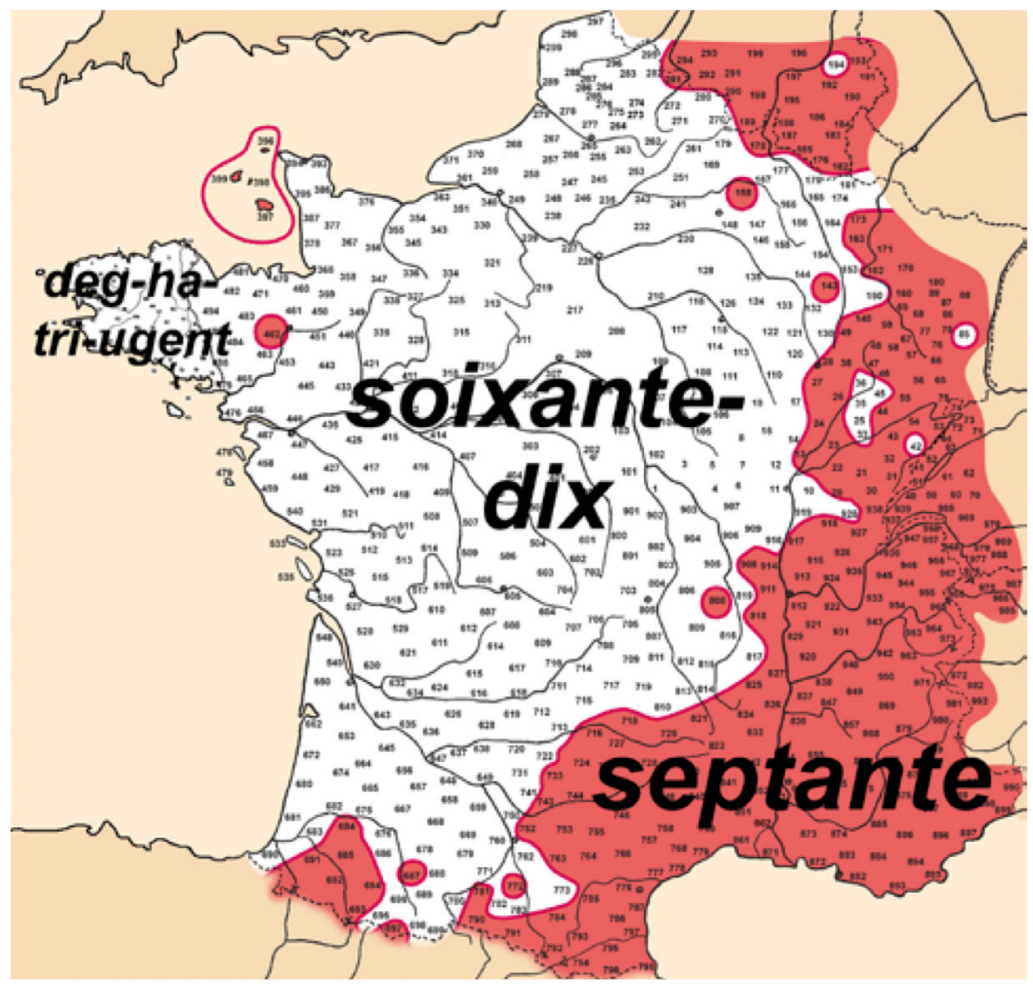

Fig. 13. The distribution of 'seventy' (Breton dek ha tri-ugent, French soixante-dix and north-eastern, eastern and south-eastern France septante)

\subsection{Dek ha tri-ugent soixante-dix 'seventy' (ALF 1240 and Bret. Dict.)}

This appears to be a spectacular example of Gaulish influence on French, just as balai in the previous example. The Celtic languages like Gaelic, Gaulish or Breton use a vigesimal numeral system (two twenties, six twenties, etc.). It seems that the Gaulish system supplanted the Latin-based septante, giving way to soixante-dix 'sixty-ten'. In Breton this is dek ha tri-ugent 'ten-and-three-twenty' (Welsh deg a thrigain 'ten and three-twenty'). Note also pevar-urgent 'four-twenty' (Welsh pedwar ugain 'four twenty") and French quatre-vingt 'four twenty'. We can interpret this change as a resurgence of the Gaulish substratum in French. The Quinze-Vingts hospital in Paris, founded in the $13^{\text {th }}$ century, was meant to house 300 (fifteen score) patients. It is speculated that the use of score for 'twenty' in English might be a calque on the Celtic vigesimal system (see Fig. 13 above). 


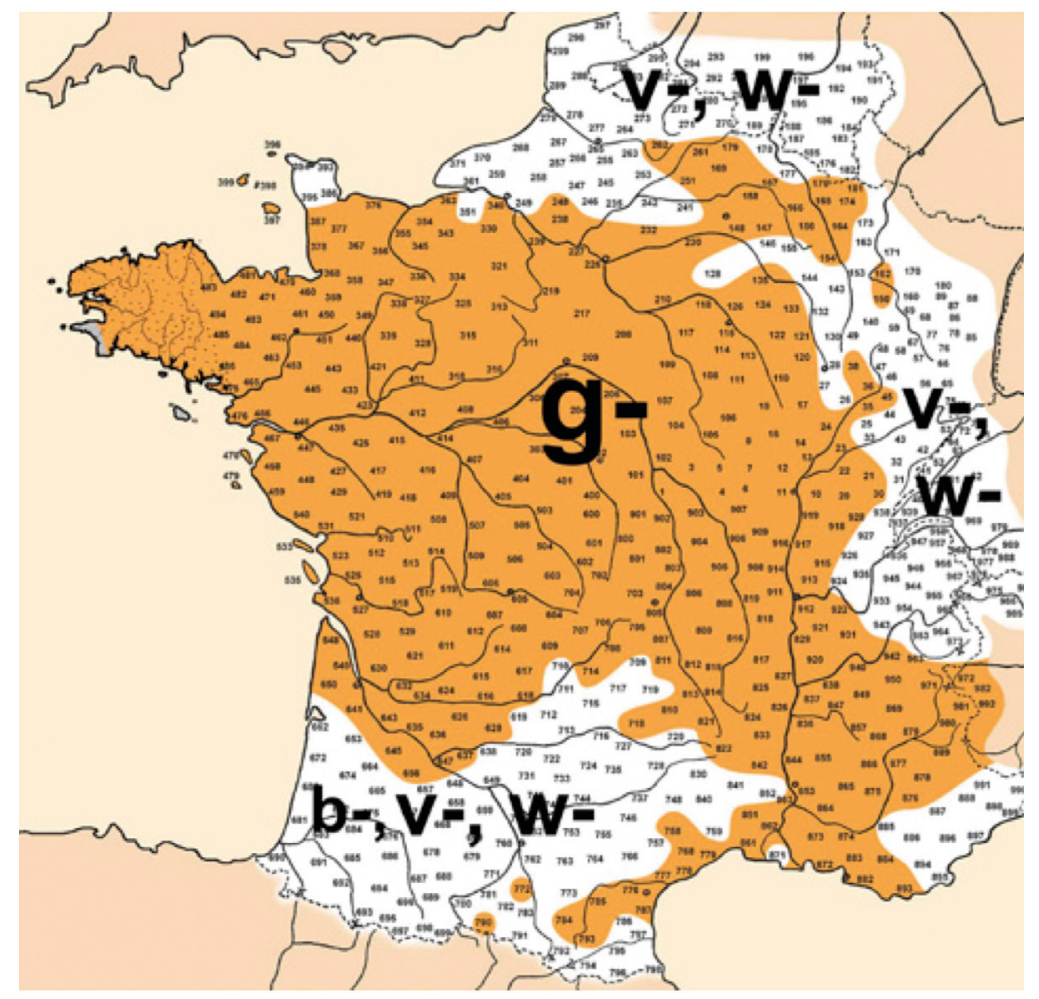

Fig. 14. Distribution of internal lenition in Breton and Occitan $b>v$ (Latin scrībō, Gascon escriver, Breton skriva); fortis initial $w$ - > Breton $g w$ - and in some French words $v$ - $>g u$ - (Latin vespa $>$ guepe 'wasp' vs. Breton gwesped 'wasps'). Note that Germanic areas have retained original $v$ - or $w$-.

\subsection{Gwesper guêpe 'wasp' (NALBB 243; ALF 672)}

We have just seen instances of Celtic lenition, a trait that marked the phonetic development of the French language. Consonants in a weak position, especially between vowels, are lenified one step further than in Breton or Occitan (e.g. Latin scrībo, Gascon escriver, Breton skriva, French écrire). On the other hand, they are strengthened in the fortis initial position, a phenomenon that is still alive today in Breton. Thus, the Middle French boest (modern French boitte) 'box' has passed into Breton: as the word is feminine, it becomes ar west after the article. From this mutated form, some dialects have 'reconstructed' a new radical or unmutated form, gwest, in a manner similar to that by which French voiture has become gwetur. The map (Fig. 14) illustrates this phenomenon: just like vernhe became gwern, vinum became gwin in Breton or Welsh, and vespa became guêpe in French (in Breton gwesped). 


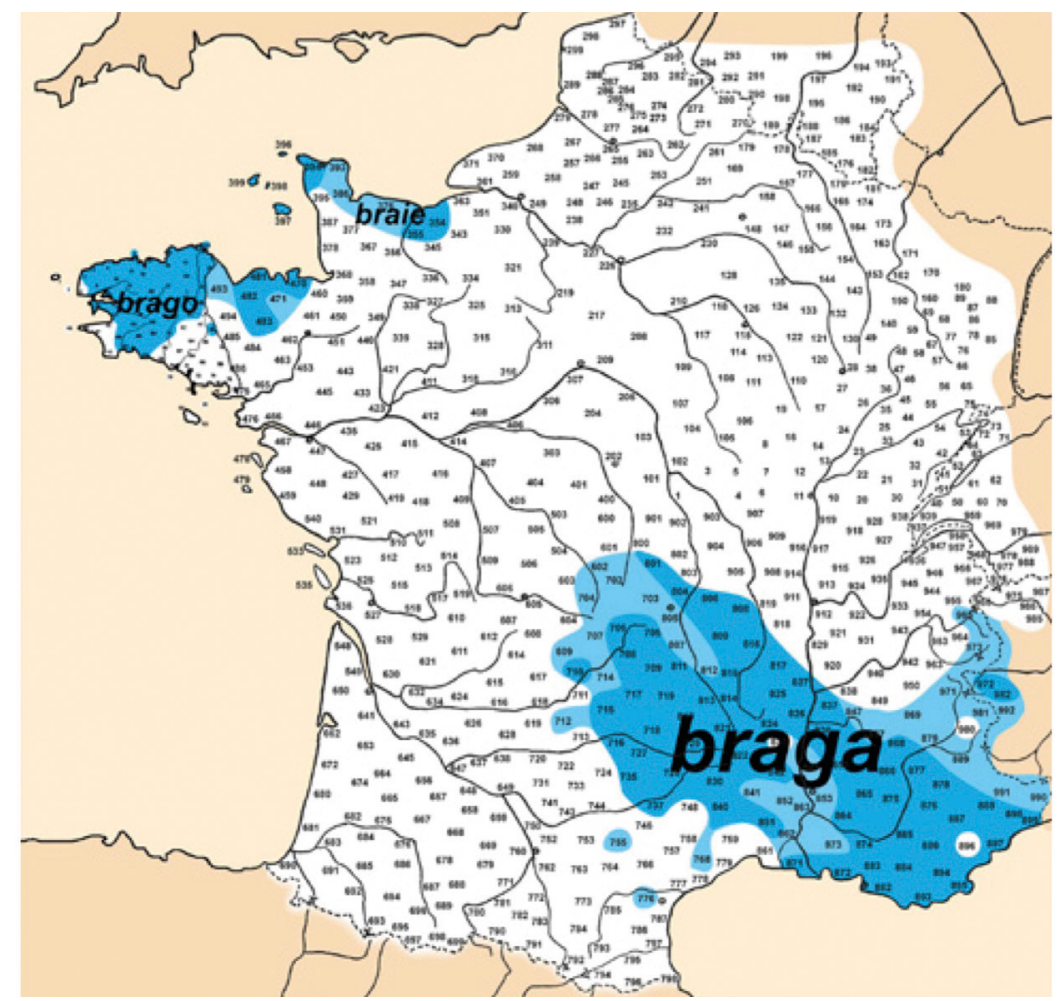

Fig. 15. The distribution of 'breeches' (Breton brago(u), central French braie, and Occitan braga)

Is it really necessary to resort to a former unattested Low Frankish *waspa crossed with Latin vespa, which does not account for the initial $g$-? Paradoxically, the northern fringe of France and Wallonia have kept initial $v$ - or $w$ !

\subsection{Brago(u) - Braga 'breeches' (ALBB 39; ALF 373)}

The word for 'pants, trousers' was braca in Gaulish. It was replaced by braies in central French, but survived in Occitan braga and Breton bragez, brago(u). Note once again the lenition of $c(/ \mathrm{k} /)$ to $g$ in both Breton and Occitan. Why, as we sometimes hear, would it have been borrowed in Breton from Lower Latin, especially if we envisage a close relationship between Breton and Gaulish (see Fig. 15)? 


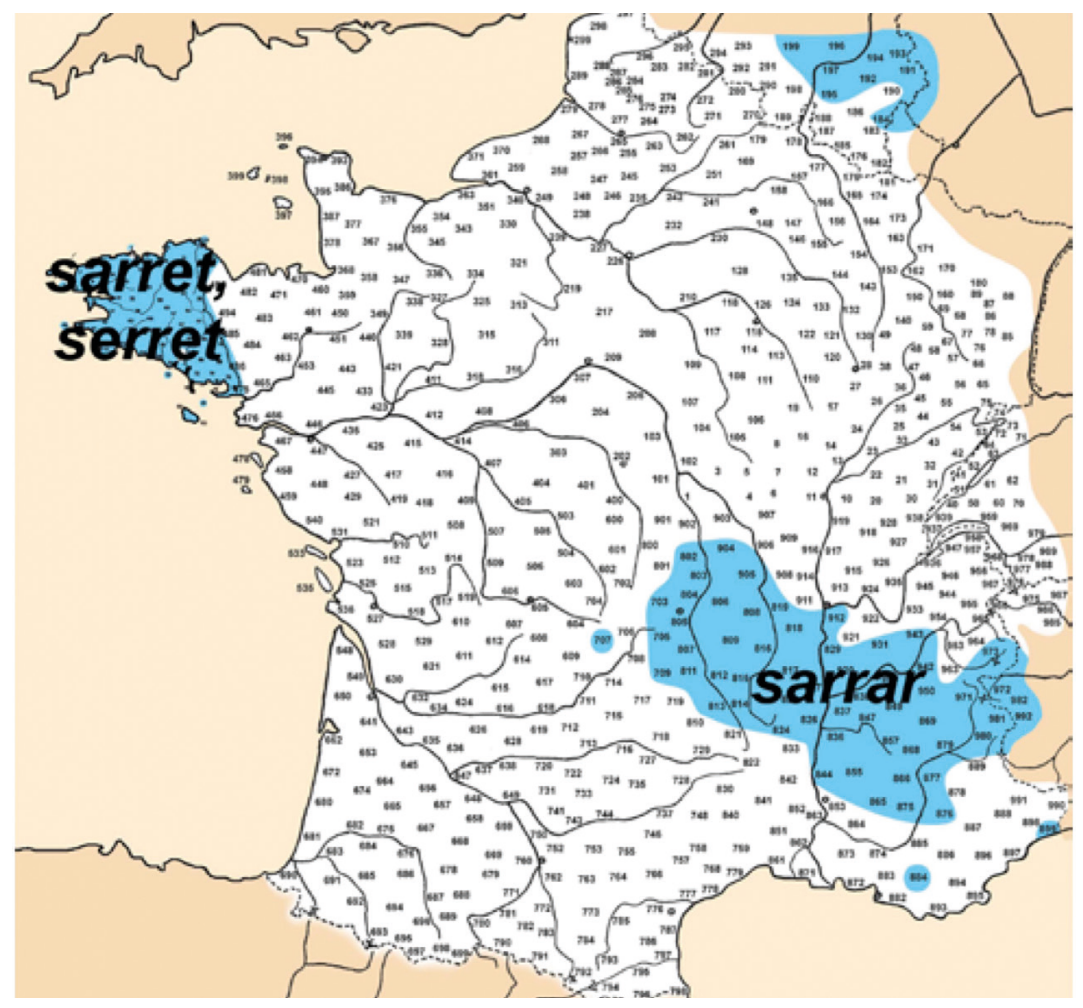

Fig. 16. The distribution of the verb 'to close' (Breton sarret, serret, and Occitan sarrar)

\subsection{Sarret - sarrar 'closed' (ALBB 559; ALF 554)}

Old Latin words borrowed in Breton, Welsh and Cornish during Roman times have undergone the same process as words of Celtic origin. This map represents forms of serrer 'to close', issued according to the CNTRL from the popular Latin *serrare, an alteration of the late Latin serare 'to close'. The analogy with the previous map (Fig. 15) is striking, to say the least (see Fig. 16). The Breton word sarret/serret is the past participle form of the word; serri $(\tilde{n})$ is the infinitive. 


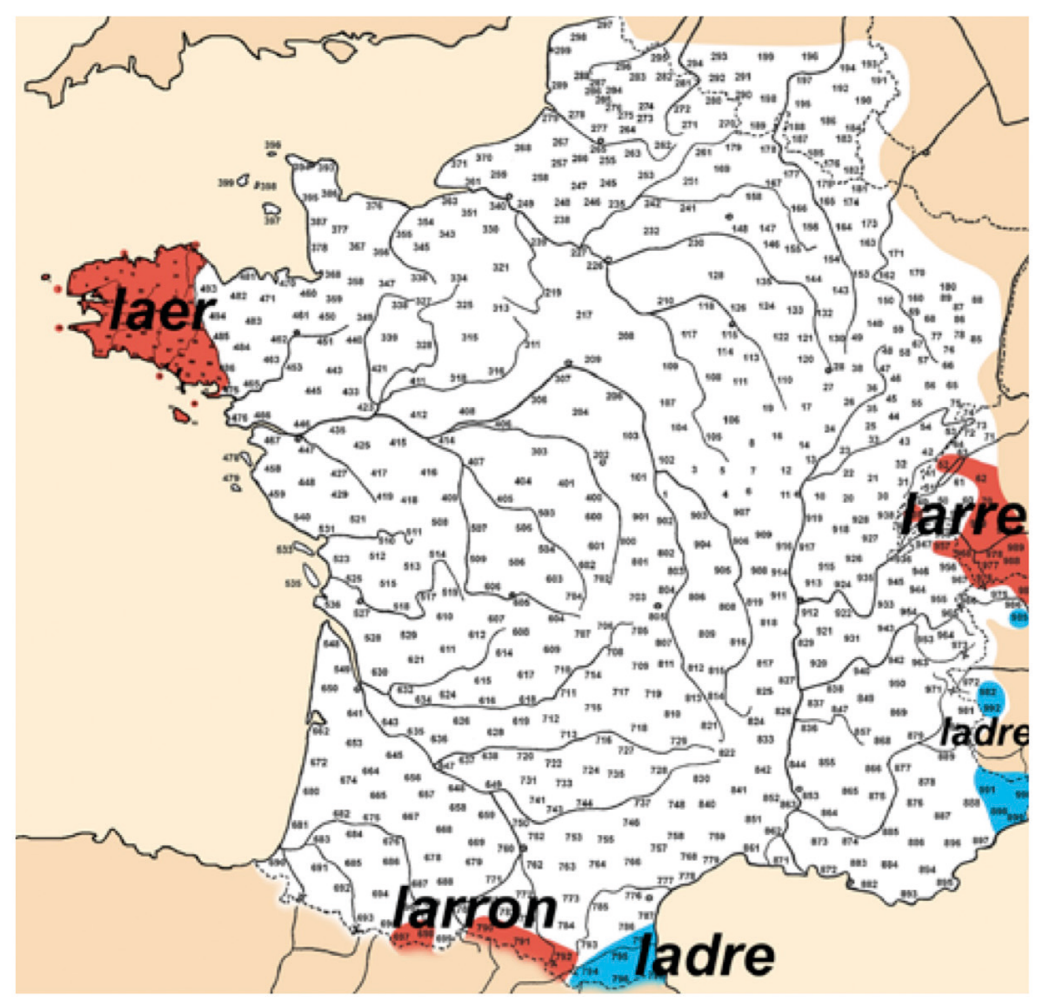

Fig. 17. The distribution of 'thief' (Breton laer, Occitan and eastern French varieties larron, ladre, larre)

\subsection{Laer - larron, ladre, larre 'thief' (ALBB 420 and ALF 1412)}

'Thief' is in Breton laer, plural laeron. The Breton spoken on the island of Ouessant (Ushant for the English sailors) has retained the $-d$ - in ladr, ladroun 'thieves' (cf. lladr / Iladron in Welsh). The Old French larron had a subjunctive lerre (inherited from Latin latrōnem, the accusative of latrō) and it would seem that the Breton word evolved from the form. Old Provençal likewise opposed laire to lairon (see Fig. 17). 


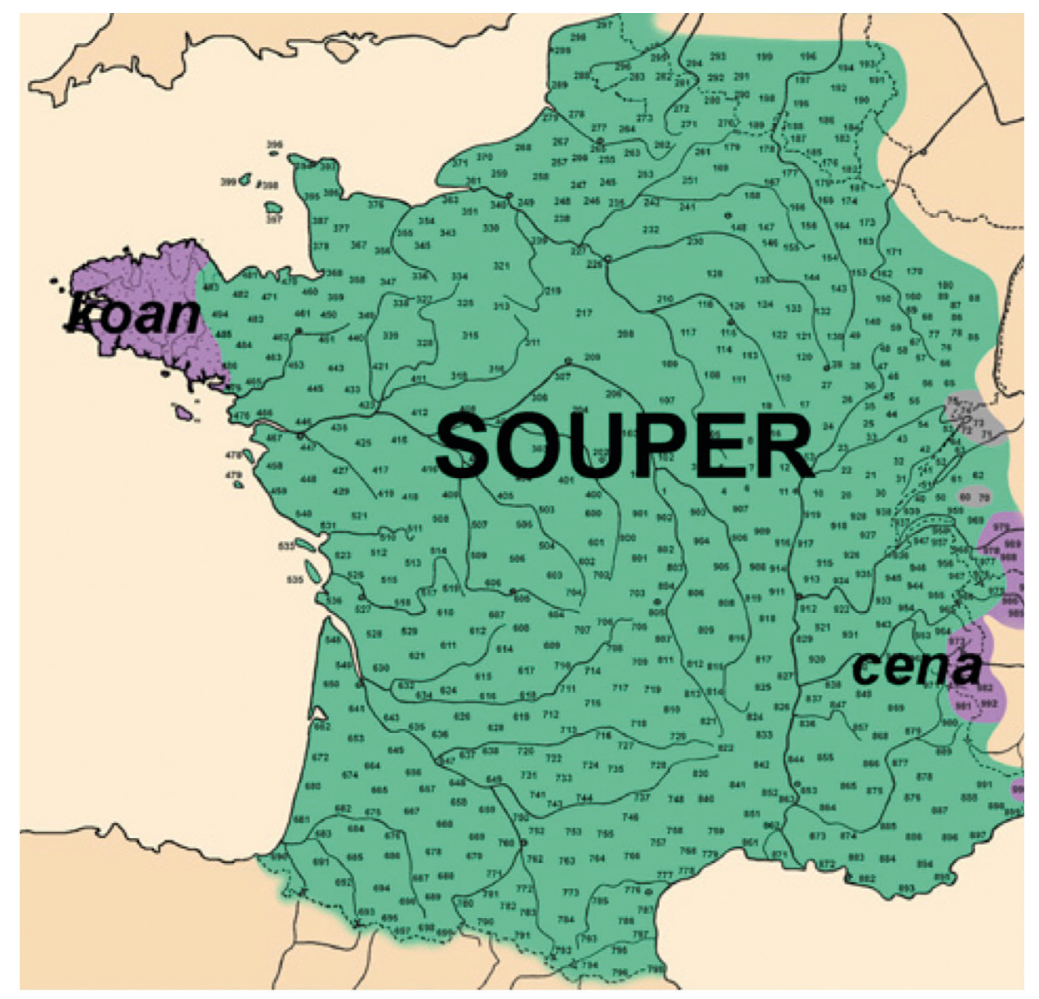

Fig. 18. The distribution of 'dinner' (Breton koan, French souper, and Occitan and eastern French varieties cena)

\subsection{Koan cena 'dinner' (evening meal) (ALBB 157; ALF 1254)}

This map (Fig. 18) represents minute areas. The Breton koan 'evening meal', from Latin cena, has kept the initial stop consonant $k$-, which has been affricated or spirantised in modern Romance languages. 


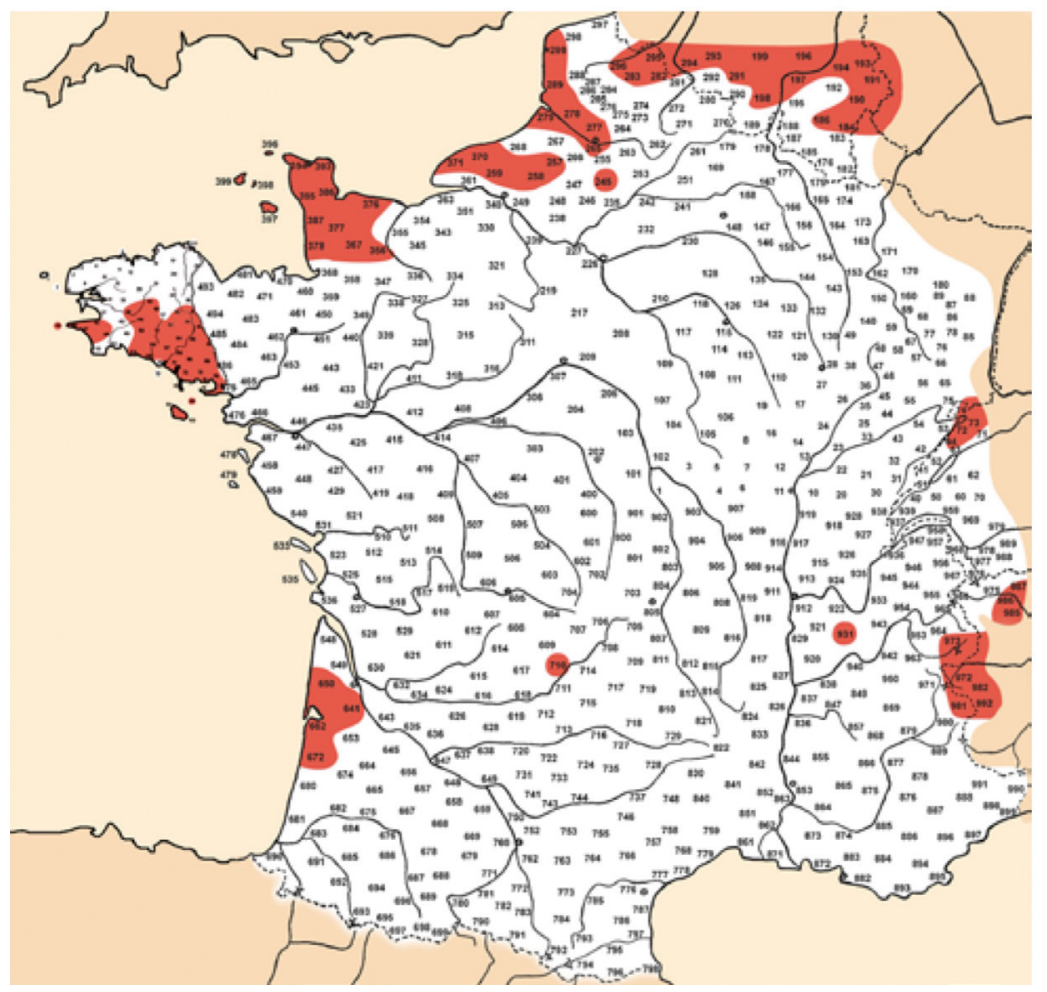

Fig. 19. The distribution of 'frog' (Breton ran or rannig, and French raine, renouille in the French Alps)

\subsection{Ran(ig) rana 'frog' (ALBB 543; ALF 668)}

We have here the example of a Latin word, rana for 'frog', which might have been used in Gaulish. It has disappeared from central French, but is still to be found in the south of Lower Brittany under the form of $\mathrm{ran}(\mathrm{ig})$ and in several small and very peripheral areas (Fig. 19). Central French has developed another word, grenouille, derived from the same root. French raine and rainette is in fact a species of grenouille (i.e. hyla arborea). Ran has remained with the sense of 'tadpole' in the north-east of Lower Brittany (i.e. Tregor). Breton also has the new word glesker, of unknown origin. 


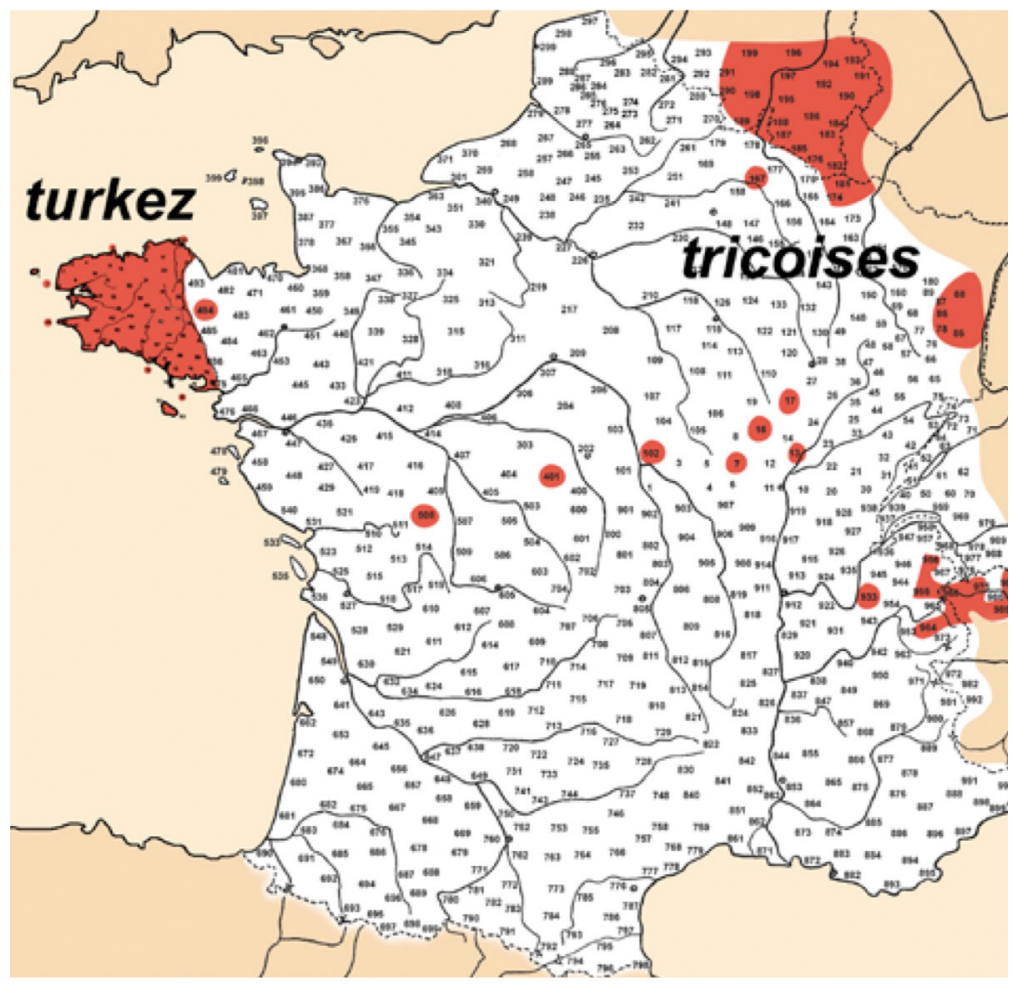

Fig. 20. The distribution of 'pincer', 'log tongs' (Breton turkez, northern and eastern French and Walloon tricoises)

\subsection{Turkez turquois 'pincer','log tongs' (NALBB 309 and ALF 1293)}

To conclude, this map (Fig. 20) shows that exchanges between Lower Brittany and the Romance areas have never ceased. The word for 'pincer', 'log tongs' is found in eastern and northern France and in the Walloon tricoises, as well as in some scattered areas. Breton has turkez, obviously of the same origin: it is the old French tricoises, turquois, turcois, a word perhaps derived from 'tenailles turcoises', meaning 'Turkish pincers'. Among its many uses, this tool can be used to displace burning logs in a fireplace. 


\section{Conclusion}

The Atlas Linguarum Europae 1983-1990 has made a great leap forward by taking the entire European continent as its field of investigation. There has naturally been a tendency since the beginnings of geolinguistics to limit the interpretation of maps to single languages, or even to language families, as AliR does. Let us note, however, that the latter project has also taken into consideration non-French peripheral points for the sake of comparison, including two points in Lower Brittany, which made it possible, in some cases (e.g. for the CRADLE map), to show that the so-called "Celtic" region was the only one in France to have kept kavell, from the word cavellum of Low Latin origin. I plead in this article in favour of this transgression of linguistic boundaries and suggest that it should be undertaken more systematically within language groups linked by geography and history. Taking Breton into account seems to me to shed new light on some aspects of the evolution of the French language, both from a lexical and a phonetic point of view.

Taking Breton into account seems to me to shed new light on some aspects of the evolution of the French language, both from a lexical and a phonetic point of view.

The addition of Basque and Alsatian and Lorraine Platt vocabulary to this discussion would no doubt enrich this research. Many problems could thus be approached with a fresh eye; the benefits would certainly be shared by all parties.

University of Western Brittany, Brest

\section{Abbreviations}

ALE = Atlas Linguarum Europae, vols. 1-4: Assen-Maastricht: Van Gorcum, 1983-1990; vols. 5-7, Rome: Istituto Poligrafico e Zecca dello Stato, 1996-2008.

AliR = Atlas Linguistique Roman, Rome: Istituto Poligrafico e Zecca dello Stato, 1986-. CNRTL $=$ Centre National de Ressources Textuelles et Lexicales. http://www.cnrtl.fr/. EHHA = Euskal Herriko Atlas Linguistikoa (Basque Linguistic Atlas).

http://www.euskaltzaindia.net/ehha.

\section{References}

Bras, M., \& Brun-Trigaud, G., 2014, 'La référence temporelle en Occitan: étude sémantique et dialectologique des noms de jours de la semaine en emploi adverbial', in: Garabato, C. A., Torreilles, C., \& Verny, M. J., eds., Los que fan viure e treslusir l'Occitan. Actes du Xe Congrès de l'Association Internationale d'Études Occitanes, Béziers, 12-19 Juin 2011, Limoges: Lambert-Lucas, 572-87. 
Diderot, D., \& D’Alembert, J., 1751-72, Encyclopédie ou Dictionnaire raisonné des sciences, des arts et des métiers, Paris: chez Briasson, David, Le Breton et Durand.

Díez, F. C., 1863, Introduction a la grammaire des langues Romanes (trans. Auguste Brachet and Gaston Paris), Paris: Librairie A. Franck.

Evans, D. E., 1990, 'Insular Celtic and the Emergence of the Welsh Language', in: Bammesberger A., \& Wollmann, A., eds., Britain 400-600: Language and History, Heidelberg: Carl Winter, 149-78.

Falc'hun, F., 1963, Histoire de la langue bretonne d'après la géographie linguistique, Paris: P.U.F.

Falc'hun, F., 1970, Problèmes de méthode en toponymie Celtique, Les noms de lieux Celtiques, deuxième série, Rennes: Éditions Armoricaines.

Falc'hun, F., 1981, Perspectives nouvelles sur l'histoire de la langue Bretonne, Paris: UGE. Fleuriot, L., 1980, Les Origines de la Bretagne, Paris: Payot.

Favereau, F., 1993, Dictionnaire du Breton contemporain, Morlaix: Skol Vreizh (http:/ www.arkaevraz.net/dicobzh/index.php).

Gilliéron, J., \& Edmont, E., 1902-10, Atlas Linguistique de la France, Paris: Champion. Lavallée, de, J., 1807, Mémoires de l'Académie Celtique: Recherches Sur Les Antiquités Celtiques, Paris: Société des antiquaire de France. Vol. 1 (4).

Le Dû, J., 2001, Nouvel Atlas Linguistique de la Basse-Bretagne, Brest: CRBC.

Le Dû, J., Brun-Trigaud, G., \& Le Berre, Y., 2005, Lectures de l'Atlas Linguistique de la France de Gilliéron et Edmont-Du temps dans l'espace, Paris: Éditions du Comité des Travaux Historiques et Scientifiques (CTHS).

Le Dû, J., \& Brun-Trigaud, G., 2018, 'Le nom français du balai', in: Perez, A., Afonson, X., \& Mercedes, B., eds., Obreiro da lingua, amigo da xente. Estudos de xeografía lingüistica en homenaxe a Manolo González, Santiago de Compostela: Universidade de Santiago de Compostela, 165-76.

Le Pelletier, D. L., 1752, Dictionnaire de la langue Bretonne, où l'on voit son Antiquité, son Affinité avec les anciennes langues, l'Explication de plusieurs passages de l'Ecriture Sainte, et des Auteurs profanes, avec l'Etymologie de plusieurs mots des autres langues, Paris: François Delaguette, Imprimeur-libraire.

Le Roux, P., 1924-63, Atlas Linguistique de la Basse-Bretagne, Paris-Rennes: Librairie Plihon \& Librairie H. Champion.

Lhuyd, E., 1707, Archaeologia Britannica, Giving Some Account Additional to What has been hitherto Published of the Languages, Histories and Customs of the Original Inhabitants of Great Britain: From Collection and Onservations in Travels through Wales, Cornwall, Bas-Bretagne, Ireland and Scotland, Oxford: The Theatre.

Loth, J., 1883, L'immigration Bretonne en Armorique du Ve au VIIe siècles de notre ère, Paris: Picard.

Mistral, F., 1879, Lou Tresor dóu Felibrige, Aix-en-Provence, Avignon, Paris: LibraireEditeur J. Remondet-Aubin, Librairie Roumainville, Librairie H. Champion. 
Pezron, P.-Y., 1703, Antiquité de la nation et de la langue des Celtes, autrement appellez Gaulois, Paris: chez Jean Boudot, Imprimeur du Roy et de l'Académie Royale des Sciences.

Potte, J.-Cl., 1975, Atlas Linguistique et Ethnographique de l'Auvergne et du Limousin, Paris: CNRS. Vol. 1.

Wartburg, von, W., 1922-2002, Französisches Etymologisches Wörterbuch. Eine Darstellung des galloromanischen Sprachschatzes. Bonn, Berlin, Basel: Klopp, Teubner, Zbinden. 25 vols. 